\title{
OBTAINING OF COUMARONE-INDENE RESINS BASED ON LIGHT FRACTION OF COAL TAR. 5. EMULSIONS ON THE BASIS OF BITUMEN MODIFIED BY COUMARONE-INDENE RESINS WITH EPOXY GROUPS
}

\author{
Iurii Sidun', Serhiy Solodkyy', Mariia Shved ${ }^{1}$, Olena Astakhova ${ }^{1}$, Olena Shyshchak ${ }^{1}$, \\ Michael Bratychak ${ }^{1, \otimes}$
}

https://doi.org/10.23939/chcht13.04.489

\begin{abstract}
The road slow-setting monophase cationic bitumen emulsions have been prepared from bitumen modified by coumarone-indene resin with epoxy groups. Emulsions were obtained using a colloid mill at the standard temperatures $(413-423 \mathrm{~K})$. The physicotechnical parameters of modified monophase emulsions have been established and the comparative analysis with the base sample has been made.
\end{abstract}

Keywords: bitumen emulsion, emulsifier, modified bitumen, coumarone-indene resin with epoxy groups.

\section{Introduction}

Bitumen without special additives does not wet stone materials, does not envelop their particles and does not adhere to them. Bitumen emulsions (BE) have not these disadvantages. Moreover, when using $\mathrm{BE}$ the consumption of bitumen is reduced by $20-30 \mathrm{wt} \%$ due to the formation of a thin bitumen film around the grains of mineral materials; emulsions and stone materials have no need to be pre-heated and thus fuel and energy resources are saved; the wet stone materials may be processed. The storage of $\mathrm{BE}$ is simple and does not require a complex heating system. The emulsions allow to work under adverse weather conditions, when it is impossible to achieve the required quality of work using hot mixtures even in the presence of surfactants. But there are also some drawbacks of using BE: the possibility of emulsion washing-out during prolonged rains; the final formation of coatings under the influence of motion is slower than that using the hot method; the coating formation requires particularly diligent care [1-3].

\footnotetext{
${ }^{1}$ Lviv Polytechnic National University

12, S.Bandery St., 79013 Lviv, Ukraine

mbratychak@gmail.com

(C) Sidun Iu., Solodkyy S., Shved M., Astakhova O., Shyshchak O., Bratychak M., 2019
}

Road bitumen emulsions are liquids of dark brown (black) color, which are obtained by dispersing (crushing) bitumen into $1-10 \mu \mathrm{m}$ particles in an aqueous solution of the emulsifier with the addition of acid or alkali. The emulsifier itself is a component of the emulsion; it is a surfactant of cationic or anionic type, which promotes the dispersion of bitumen and ensures the emulsion stability during storage and transportation. Cationic type is based on derivatives of higher aliphatic amines (mono-, di- and polyamines), as well as quaternary ammonium salts. Anionic type is based on salts (soaps) of higher natural or synthetic carboxylic fatty acids (fractions $\mathrm{C}_{17}-\mathrm{C}_{20}, \mathrm{C}_{21}$ $\mathrm{C}_{25}$ ) or their vat residues. The emulsion may include polymeric, adhesive and other additives. As a result, there are two types of modified bitumen emulsion: the first type is prepared on the basis of modified bitumen (monophase emulsion) and the second one is the emulsion modified after preparation (two-phase emulsion).

Thermoelastoplastics (first of all, styrene block copolymers of SBS type) are widely used for RBE modification due to their ability not only to increase the bitumen strength, but also to provide polymerized bitumen with elasticity, including that at low temperatures. Thermoelastoplastics retain their highly elastic strain capability in the temperature range from 193 to $353 \mathrm{~K}$; their destruction temperature is $463-483 \mathrm{~K}$. The content of such polymers in bitumen can reach 3-10 wt \% [4-7]. The main reason limiting the increase in the production of polymer modified bitumen (PMB) is their high cost (1.5-2.5 times higher than the cost of unmodified bitumen) [8, 9].

Recently, at the Department of Chemical Technology of Oil and Gas Processing at Lviv Polytechnic National University, new bitumen modifiers have been developed based on petroleum [11-13], phenolformaldehyde [14-16], epoxy [16] and coumarone-indene resins without [17-18] and with functional groups [19-22]. The most promising results were obtained for coumarone- 
indene resins with functional groups, since they are produced from a light fraction of coal tar, which is available and low cost by-product of coal coking.

The aim of this work was to produce bitumen emulsions from bitumen modified by indene-coumarone resin with epoxy groups (CIRE) and to study their properties.

\section{Experimental}

\subsection{Initial Materials}

BND 60/90 bitumen produced by PJSC "Ukrtatnafta" (Kremenchuk, Ukraine) was used. The characteristics of pure and modified bitumen are given in Table 1, the changes in bitumen properties after heating are represented in Table 2.
According to recipe, bitumen emulsions contained Redicote E-11 (Nouryon, Sweden) emulsifier (Table 3).

CIRE was synthesized on the basis of light fraction of coal tar (LFCT), purchased from PJSC "Zaporizhkoks" (Ukraine). The LFCT composition is given in Table 4. synthesis:

The following materials were also used for CIRE

- Monoperoxy derivative of diglycidyl ether Bisphenol A (PO), synthesized according to the procedure described in [22]. For PO: molecular weight $430 \mathrm{~g} / \mathrm{mol}$, active oxygen content $2.5 \%$ and content of epoxy groups $8.8 \%$;

- Glycidyl methacrylate was purchased from Aldrich (USA) with $n_{D}^{20} 1.449, d_{4}^{20} 1.042$;

- Styrene was dried before the experiments with solid alkali and purified by distillation at $323 \mathrm{~K}$ under residual pressure of $300-400 \mathrm{~Pa}$. Its characteristic: $n_{D}^{20} 1.5471, d_{4}^{20} 0.902$.

Table 1

Physico-mechanical properties of pure and modified bitumen

\begin{tabular}{|c|c|c|c|c|c|c|c|c|}
\hline \multirow[b]{3}{*}{ Bitumen } & \multicolumn{8}{|c|}{ Parameters } \\
\hline & \multirow[b]{2}{*}{$\begin{array}{l}\text { Softening } \\
\text { point, } T_{s}, \\
\mathrm{~K}\end{array}$} & \multirow[b]{2}{*}{$\begin{array}{l}\text { Penetration } \\
\text { at } 298 \mathrm{~K} \text {, } \\
P_{298}, 10^{-4} \mathrm{~m}\end{array}$} & \multirow[b]{2}{*}{$\begin{array}{c}\text { Ductility at } \\
298 \mathrm{~K}, D_{298} \text {, } \\
\mathrm{m} \cdot 10^{-2}\end{array}$} & \multirow[b]{2}{*}{$\begin{array}{c}\text { Fraass } \\
\text { breaking } \\
\text { point, } T_{f}, \mathrm{~K}\end{array}$} & \multirow[b]{2}{*}{$\begin{array}{l}\text { Plasticity } \\
\text { range, K }\end{array}$} & \multirow[b]{2}{*}{$\begin{array}{l}\text { Penetration } \\
\text { index }\end{array}$} & \multicolumn{2}{|c|}{ Adhesion to } \\
\hline & & & & & & & $\begin{array}{l}\text { crushed } \\
\text { stone, } \\
\text { points }\end{array}$ & $\begin{array}{c}\text { glass, } \\
\%\end{array}$ \\
\hline BND 60/90 & 319 & 70 & 63 & 255 & 64 & -1.5 & 3 & 33 \\
\hline BND 60/90+CIRE & 322 & 57 & 82 & - & - & - & 5 & 84 \\
\hline
\end{tabular}

Table 2

Physico-mechanical properties of bitumen after heating

\begin{tabular}{|l|c|c|c|c|}
\hline \multirow{2}{*}{ Bitumen } & \multicolumn{3}{|c|}{ Parameters } \\
\cline { 2 - 5 } & $\begin{array}{c}\text { Change in } \\
\text { softening point, } \mathrm{K}\end{array}$ & $\begin{array}{c}\text { Residual penetration } \\
\text { at 298 K, 10 } \mathrm{m}\end{array}$ & $\begin{array}{c}\text { Adhesion to } \\
\text { crushed stone, } \\
\text { points }\end{array}$ & $\begin{array}{c}\text { glass, } \\
\%\end{array}$ \\
\hline BND 60/90 & +2 & 93 & 3 & 43 \\
\hline BND 60/90+CIRE & +2 & 91 & 5 & 92 \\
\hline
\end{tabular}

Table 3

Characteristics of Redicote E-11 emulsifier for slow setting cationic $B E$

\begin{tabular}{|l|l|}
\hline \multicolumn{1}{|c|}{ Appearance } & \multicolumn{1}{|c|}{ Liquid at 298 K } \\
\hline $\mathrm{pH}$ & $6-9(5 \%$ in $50 / 502$-propanol/water $)$ \\
\hline Active content, \% & $48-53$ (solid)- \\
\hline Density at $293 \mathrm{~K}, \mathrm{~kg} / \mathrm{m}^{3}$ & 900 \\
\hline Flash point, $\mathrm{K}$ & 291 \\
\hline Pour point, K & 253 \\
\hline Viscosity at $293 \mathrm{~K}, \mathrm{mPa} \cdot \mathrm{s}$ & 50 \\
\hline Solubility in water & Soluble \\
\hline
\end{tabular}


Components content in LFCT

\begin{tabular}{|c|c|}
\hline Component & Content, wt \% \\
\hline Benzene & 0.98 \\
\hline Toluene & 1.23 \\
\hline Ethylbenzene & 0.32 \\
\hline$m+p$-Xylenes & 8.10 \\
\hline$o$-Xylene & 2.61 \\
\hline Styrene & 6.73 \\
\hline$o$-Ethylbenzene & 4.35 \\
\hline Pseudocumene & 7.71 \\
\hline Hidrindane & 2.64 \\
\hline Coumarone & 5.75 \\
\hline Indene & 44.45 \\
\hline Naphthalene & 6.96 \\
\hline$\beta$-Methylnaphthalene & 0.31 \\
\hline$\alpha$-Methylnaphthalene & 0.13 \\
\hline Other hydrocarbons & 7.73 \\
\hline Total & 100.0 \\
\hline
\end{tabular}

\subsection{CIRE Synthesis}

CIRE was synthesized in the metal ampoules by the volume of $1000 \mathrm{ml} .250 \mathrm{ml}(244.0 \mathrm{~g})$ of LFCT, $30 \mathrm{ml}$ $(27.2 \mathrm{~g})$ of styrene, $20 \mathrm{ml}(23.0 \mathrm{~g})$ of glycidyl methacrylate (GMA), and $12.5 \mathrm{~g}$ of PO were loaded into the ampoule. Then, the system was blown with an inert gas, closed and placed in a thermostat. Radical cooligomerization proceeded at $393 \mathrm{~K}$ for $6 \mathrm{~h}$. After cooligomerization, the ampoule was cooled to room temperature, the reaction mixture was transferred to a distillation flask and unreacted raw material was distilled under vacuum. The resulting product was dried in a vacuum-dryer at $313 \mathrm{~K}$ to a constant weight. $100.0 \mathrm{~g}$ of CIRE with a molecular weight of $920 \mathrm{~g} / \mathrm{mol}$ and content of epoxy groups $2.1 \%$ were obtained.
IR-spectroscopy was used to confirm the structure of CIRE (Fig. 1). The presence of epoxy groups in the synthesized resin is confirmed by the absorption band at $944 \mathrm{~cm}^{-1}$. The presence of $\mathrm{OH}$ group in coumarone-indene resin formed due to the initiation of unsaturated compounds in the initial mixture by PO is confirmed by the absorption band at $3368 \mathrm{~cm}^{-1}$. Moreover, the $\mathrm{H}_{3} \mathrm{C}-\mathrm{C}-\mathrm{CH}_{3}$ fragment in the resin structure is confirmed by gel-dimethyl vibrations at 1384 and $1356 \mathrm{~cm}^{-1}$; the etheric bond - at $1172 \mathrm{~cm}^{-1}$; benzene rings - at 1600 and $1512 \mathrm{~cm}^{-1}$. The entering of GMA molecule with the esteric bond into the resin structure is confirmed by absorption bands at 1720, 1244 and $1046 \mathrm{~cm}^{-1}$.

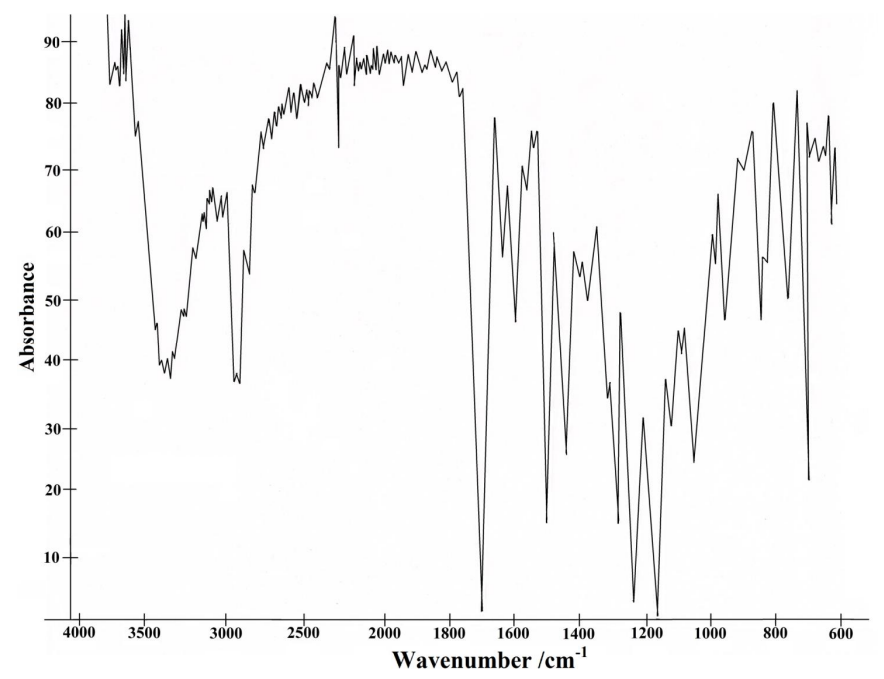

Fig. 1. IR spectrum of CIRE 


\subsection{Analytical Determination}

The number-average molecular weight $\left(M_{n}\right)$ of the synthesized CIRE was determined using cryoscopy in benzene. The content of epoxy groups (epoxy number, e.n.) was determined according to the procedure described in [23].

\subsection{Spectral Measurements}

IR spectra were recorded using "Specord-80" spectrophotometer (Zeiss, Germany) with the relevant absorbance range of $4000-400 \mathrm{~cm}^{-1}$. The samples were dissolved in acetone and obtained films were applied over the plate with $\mathrm{KBr}$ (layer thickness was $0.03 \mathrm{~mm}$ ).

\subsection{Preparation and Analysis of PMB and $\mathrm{BE}$}

To prepare polymer modified bitumen (PMB) $99 \mathrm{wt} \%$ of BND $60 / 90$ was heated to $463 \mathrm{~K}$ and then $1 \mathrm{wt} \%$ of the modifier (CIRE) was added. The modification was carried out for $1 \mathrm{~h}$ under constant stirring $(\operatorname{Re}=1200)$. For bitumen and PMB the softening temperature ("ball and ring" method), penetration, ductility, bitumen properties after heating, adhesion to crushed stone and glass were determined according to the procedures described in [4, 24-28].

The bitumen emulsions were prepared in several steps:

- preparation of the "aqueous phase";

- preparation of the "bitumen phase";

- mixing of two phases at the laboratory bitumen emulsion plant SEP-0.3R (DenimoTECH, Denmark) equipped with a colloid mill.

The aqueous and bitumen phases were placed in special containers of the plant and heated to the required temperature $(323 \mathrm{~K}$ for aqueous phase, $413-423 \mathrm{~K}$ for bitumen). BE was obtained by mixing the phases. The number of components in the emulsion was calculated according to its recipe using a computer program.

Physico-technical characteristics of BE (appearance, $\mathrm{pH}$, homogeneity, binding agent residual content, viscosity at $293 \mathrm{~K}$, storage stability, adhesion, miscibility with mixtures of grain composition, breaking index) were investigated according to [29]. Particle's morphology was determined using a Hitachi S-4700 Field Emission Scanning Electron Microscope (Japan).

\section{Results and Discussion}

Monophase emulsions were produced on the basis of pure (BE1) and modified (BE2 and BE2a) bitumen
(Table 5). The amount of Redicote E-11 emulsifier in $\mathrm{BE} 2 \mathrm{a}$ was lower than recommended by the recipe for slow setting emulsions. Among the rapid setting, medium setting and slow setting emulsions the latter were chosen because this type of emulsion is recommended for the manufacture of Slurry Surfacing mix, the development of which is the next stage of the study.

In general, modified emulsions are obtained according to the same scheme as unmodified ones, except for the stage of the modifier introduction. As it was mentioned above, according to the preparation technology the modified emulsions are divided into mono- and twophase ones. Monophase modified BE are prepared on the basis of modified bitumen, i.e. the modifier (modifying agent) has already been introduced into the bitumen. In most cases, the high viscosity of the modified bitumen forces to use a higher temperature for their dispersion compared to unmodified emulsions. As a result, the emulsion temperature at the outlet of the colloidal mill may be above $373 \mathrm{~K}$. Under such conditions, traditional equipment needs to be modified to make it serviceable at $(1.5-2.0) \cdot 10^{5} \mathrm{~Pa}$ and a cooling system (usually a heat exchanger) at the outlet of the mixer is needed. In the case of two-phase modified emulsions, the modifier is added in the form of an emulsion system (latex). Latex may be introduced by various ways: by dispersing in the aqueous phase; by injecting directly into the dispersed (bitumen) phase; by direct injection into a colloid mill or by addition to the resulted bitumen emulsion.

The technological advantage of CIRE-modified bitumen is that they allow to produce monophase bitumen emulsions at standard temperatures needed for unmodified emulsions preparation (413-423 K). These additives do not provide bitumen with elasticity and increase its viscosity.

Table 6 shows the physical and technical characteristics of monophased modified emulsions in comparison with the base sample. The base sample BE1 (according to Ukrainian standards [29]) corresponds to ECS-60, and the CIRE-modified samples correspond to the ECSM-60. The sample BE2a is characterized by a lower breaking index and storage stability, which is explained by the lower amount of emulsifier in it. Thus, to obtain a qualitative modified bitumen emulsion, we do not counsel to reduce the amount of emulsifier below the recommended value, because the emulsion with a lower amount of emulsifier does not meet the requirements of standards [29].

Micrograph of BE2 is represented in Fig. 2. It is seen that the bitumen droplets size in the emulsion is within $1-20 \mu \mathrm{m}$ in diameter. The droplets are distributed uniformly in the emulsion volume. 
Compositions of bitumen emulsions

\begin{tabular}{|c|c|c|c|c|}
\hline \multirow{2}{*}{ Emulsion } & \multicolumn{3}{|c|}{ Content of components in the emulsion, wt \% } \\
& \multirow{2}{*}{ Bitumen } & Redicote E-11 & Hydrochloric acid & \multirow{2}{*}{ Water } \\
\hline BE1 & \multirow{2}{*}{62.0} & 1.1 & \multirow{2}{*}{$\begin{array}{c}\text { till } \mathrm{pH}=2.5 \text { in aqueous } \\
\text { phase }\end{array}$} & \multirow{2}{*}{ till 100} \\
BE2 & & 1.1 & 0.9 & \\
BE2a & & &
\end{tabular}

Table 6

Physico-technical characteristics of BE

\begin{tabular}{|c|c|c|c|c|c|c|}
\hline \multirow{2}{*}{\multicolumn{2}{|c|}{ Index }} & \multicolumn{2}{|c|}{ Requirements according to [29] } & \multicolumn{3}{|c|}{ Emulsion } \\
\hline & & ECS-60 & ECSM-60 & BE1 & BE2 & BE2a \\
\hline \multicolumn{2}{|l|}{ Appearance } & \multicolumn{2}{|c|}{ Homogeneous dark-brown liquid } & \multicolumn{3}{|c|}{ Fits the requirements } \\
\hline \multicolumn{2}{|l|}{ Hydrogen ions concentration, $\mathrm{pH}$} & \multicolumn{2}{|c|}{$1.5-6.5$} & 3.10 & 3.9 & 4.0 \\
\hline \multicolumn{2}{|c|}{ Homogeneity (residue on sieve No.014), $\%$, no more than } & 0.25 & 0.3 & 0.05 & 0.08 & 0.1 \\
\hline \multicolumn{2}{|l|}{ Content of residual binding agent } & \multicolumn{2}{|c|}{$58-62$} & 61.02 & 61.2 & 61.25 \\
\hline \multicolumn{2}{|c|}{ Relative viscosity at $293 \mathrm{~K}$ (apparatus with hole diameter of $4 \mathrm{~mm}$ ), $\mathrm{s}$} & \multicolumn{2}{|c|}{$5-25$} & 9.8 & 11.2 & 11.8 \\
\hline \multicolumn{2}{|c|}{$\begin{array}{l}\text { Stability during storage } \\
\text { - after } 7 \text { days, (residue on sieve No.014), \%, no more than } \\
\text { - after } 30 \text { days (residue on sieve No.014), \%, no more than }\end{array}$} & $\begin{array}{l}0.3 \\
0.4\end{array}$ & $\begin{array}{l}0.4 \\
0.5\end{array}$ & $\begin{array}{l}0.11 \\
0.20\end{array}$ & $\begin{array}{l}0.38 \\
0.42\end{array}$ & $\begin{array}{l}0.39 \\
0.49\end{array}$ \\
\hline \multicolumn{2}{|c|}{ Adhesion of residual binding agent to macadam, points, no less than } & \multicolumn{2}{|c|}{5.0} & 5.0 & 5.0 & 5.0 \\
\hline \multirow{2}{*}{ Miscibility with mixtures of grained composition } & porous & \multirow{2}{*}{\multicolumn{2}{|c|}{$\begin{array}{l}\text { Yes } \\
\text { Yes }\end{array}$}} & Yes & Yes & Yes \\
\hline & dense & & & Yes & Yes & Yes \\
\hline \multicolumn{2}{|l|}{ Breaking index, \% } & \multicolumn{2}{|c|}{$170-230$} & 210.25 & 200.7 & 172.8 \\
\hline
\end{tabular}

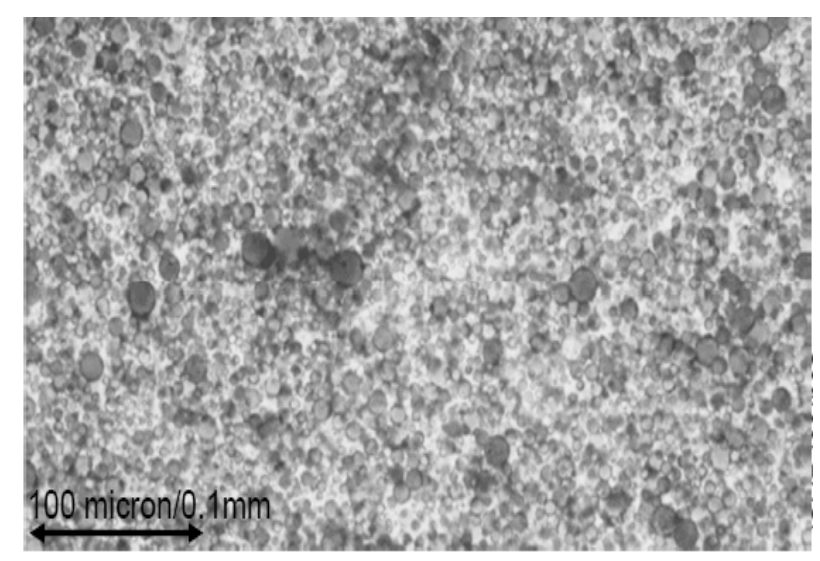

Fig. 2. Micrograph of BE2

\section{Conclusions}

The possibility of obtaining cationic road bitumen emulsions based on CIRE-modified bitumen has been proved. The produced emulsions are characterized by improved physical and mechanical properties. In addition to the increase in heat resistance and elongation of bitumen, the CIRE modifier significantly improves the adhesion of bituminous binder to mineral surfaces. The residual binding agent obtained after the bitumen emulsion breakdown will have the properties of the original CIRE-modified bitumen and improve the quality of the final road products. The technological advantage of CIRE-modified bitumen for the production of emulsions is that they do not require increased heating, as is the case with bitumen modified by usual polymers.

\section{Acknowledgments}

The work was carried out under financial support of the grant DB/Bitum No. $0117 \mathrm{U} 004451$ of the Ministry of Education and Science of Ukraine. 


\section{References}

[1] Sidun Iu., Solodkyy S., Vollis O.: J. Civil Eng., Environ., Architect., 2018, XXXV, 83. http://doi.prz.edu.pl/pl/pdf/biis/1063 [2] Pyshyev S., Grytsenko Y., Solodkyy S. et al.: Chem. Chem. Technol., 2015, 9, 359. https://doi.org/10.23939/chcht09.03.359 [3] Sidun Iu., Vollis O., Solodkyy S. et al.: [in:] Blikharskyy Z., Koszelnik P., Mesaros P. (Eds.), Lecture Notes in Civil Engineering. CEE 2019: Proceedings of CEE 2019. Springer 2019, 47, 420. https://doi.org/10.1007/978-3-030-27011-7 53

[4] Demchuk Y., Sidun Iu., Gunka V. et al.: Chem. Chem. Technol., 2018, 12, 456. https://doi.org/10.23939/chcht12.04.456

[5] Gunka V., Sidun Iu., Solodkyy S. et al.: [in:] Blikharskyy Z., Koszelnik P., Mesaros P. (Eds.), Lecture Notes in Civil Engineering. CEE 2019: Proceedings of CEE 2019. Springer 2019, 47, 111. https://doi.org/10.1007/978-3-030-27011-7_14

[6] Pyshyev S., Demchuk Yu., Gunka V. et al.: Chem. Chem. Technol., 2019, 13, 212. https://doi.org/10.23939/chcht13.02.212 [7] Hrynchuk Yu., Sidun Iu., Gunka V. et al.: Pet. Coal, 2019, 61, 836.

[8] Pyshyev S., Gunka V., Grytsenko Y. et al.: Chem. Chem. Technol., 2016, 10, 631. https://doi.org/10.23939/chcht10.04si.631 [9] Kichshynsky S.: Visnyk KhADU, 2008, 40, 28.

[10] Zhu J.: Eur. Polym. J., 2014, 54, 18. https://doi.org/10.1016/j.eurpolymj.2014.02.005

[11] Bratychak M., Chervinskyy T., Astakhova O. et al.: Chem. Chem. Technol., 2010, 4, 325.

[12] Bratychak M., Grynyshyn O., Astakhova O. et al.: Ecolog. Chem. Eng. S, 2010, 17, 309.

[13] Grynyshyn O., Astakhova O., Chervinskyy T.: Chem. Chem. Technol., 2010, 4, 241.

[14] Strap G., Astakhova O., Lazorko O. et al.: Chem. Chem. Technol., 2013, 7, 279. https://doi.org/10.23939/chcht07.03.279 [15] Gunka V., Demchuk Yu., Pyshyev S. et al: Pet. Coal, 2018, 60, 1199.

[16] Bratychak M., Iatsyshyn O., Shyshchak O. et al.: Chem. Chem. Technol., 2017, 11, 49. https://doi.org/10.23939/chcht11.01.049

[17] Pyshyev S., Grytsenko Y., Nykulyshyn I. et al.: Uglekhim. Zh., 2014, 5, C. 41.

[18] Pyshyev S., Grytsenko Y., Bilushchak H. et al.: Pet. Coal, 2015, 57, 303.

[19] BratychakM., Astakhova O., Shyshchak O. et al.: Chem. Chem. Technol., 2017, 11, 509.

https://doi.org/10.23939/chcht11.04.509

[20] Bratychak M., Ripak O., Namiesnik J. et al.: Chem. Chem. Technol., 2018, 12, 93. https://doi.org/10.23939/chcht12.01.093
[21] Bratychak M., Astakhova O., Prysiazhnyi Y. et al.: Chem. Chem. Technol., 2018, 12, 379.

https://doi.org/10.23939/chcht12.03.379

[22] Astakhova O., Shved M., Zubal O. et al.: Chem. Chem. Technol., 2019, 13, 112. https://doi.org/10.23939/chcht13.01.112 [23] Braun D., Cherdron H., Rehahn M. et al.: Polymer Synthesis: Theory and Practice. Springer-Verlag, Berlin Heidelberg 2013. https://doi.org/10.1007/b138247

[24] BS EN 1426:2000. European Standard. Bitumen and bituminous binders. Methods of tests for petroleum and its products. Determination of needle penetration.

[25] BS EN 13589:2008. European Standard. Bitumen and bituminous binders. Determination of the tensile properties of modified bitumen by the force ductility method.

[26] BS EN 1427:2007. European Standard. Bitumen and bituminous binders. Determination of the softening point. Ring and Ball method.

[27] BS EN 13614:2011. European Standard. Bitumen and bituminous binders. Determination of adhesivity of ituminous emulstions by water immersion test.

[28] EN 12591:2009 Bitumen and bituminous binders Specifications for paving grade bitumens.

[29] http://online.budstandart.com/ua/catalog/docpage?id_doc $=54091$

Received: January 28, 2019 / Revised: February 13, 2019 / Accepted: June 15, 2019

\section{ОДЕРЖАННЯ ІНДЕН-КУМАРОНОВИХ СМОЛ З ЛЕГКОЇ ФРАКЦІЇ КАМ'ЯНОВУГІЛЬНОЇ СМОЛИ. 5. ЕМУЛЬСІЇ НА ОСНОВІ БІТУМІВ, МОДИФІКОВАНИХ ІНДЕН-КУМАРОНОВОЮ СМОЛОЮ 3 ЕПОКСИДНИМИ ГРУПАМИ}

\begin{abstract}
Анотація. 3 бітумів, модифікованих інден-кумароновою смолою з епоксидними групами, виготовлені дорожні повільноразпадні монофазні катіонні бітумні емульсії. Емульсії одержано з використанням колоїдного млина, за стандартних температур (413-423 K). Встановлено фізико-технічні показники монофазних модифікованих емульсї та здійснено їх порівняльний аналіз з базовим зразком.
\end{abstract}

Ключові слова: бітумні емульсї, емульгатор, модифікований бітум, інден-кумаронова смола з епоксидними групами. 